\title{
CARACTERIZAÇÃO E AVALIAÇÃO DAS ATIVIDADES ANTIMICROBIANA DE HIDROGÉIS CONTENDO CARREADORES LIPÍDICOS COM CIPROFLOXACINA
}

\section{Talita C. Mendonça*, Simone R. Castro, Marcelo Lancellotti, Lígia N. M. Ribeiro, Eneida de Paula}

\section{Resumo}

A ciprofloxacina (CIP), um agente antibacteriano de amplo espectro e da família das fluoroquinolonas, bloqueia a atividade da DNA girase bacteriana. Os carreadores lipídicos nanoestruturados (CLN) são veículos para liberação sustentada de fármacos muito apropriados para compostos hidrofóbicos, melhorando sua estabilidade, biodisponibilidade e potência. Os hidrogéis são redes tridimensionais poliméricas, cuja interação com a água é termodinamicamente favorável, sendo capazes de absorver grandes quantidades de água ou de produtos bioativos e inchar, em meio aquoso. Este trabalho descreve o desenvolvimento e caracterização físico-química de CLN contendo CIP e incorporados em hidrogéis. As nanopartículas CLN-CIP apresentaram diâmetro médio de $240 \mathrm{~nm}$ com baixa polidispersão de tamanhos (PDI < 0,2) e potencial zeta negativo: $P Z=\mid 26,1$ a 39,1 $\mid \mathrm{mV}$. Mesmo após incorporação em hidrogéis de alginato (AL) ou poloxamer ato188 (PL), as nanoparticulas se mantiveram íntegras e com as mesmas características. Ensaios de liberação in vitro revelaram liberação sustentada do fármaco, tanto para CLN-CIP quanto para CLN-CIP incorporada nos hidrogéis, com percentuais de $97 \%$ e $71 \%$ de liberação, respectivmente, após $24 \mathrm{~h}$.

\section{Palavras-chave:}

Ciprofloxacina, carreadores lípidicos nanoestruturados, hidrogéis.

\section{Introdução}

A ciprofloxacina (CIP) pertence à segunda geração de fluoroquinolonas e é um bactericida que bloqueia a atividade da DNA girase das bactérias ${ }^{1}$. Os carreadores lipídicos nanoestruturados (CLN) são nanopartículas constituídas internamente por uma mistura de lipídio sólido e líquido, e estabilizadas por um tensoativo². Os hidrogéis são redes tridimensionais poliméricas, hidrofílicas, capazes de absorver grandes quantidades de água ou de produtos bioativos ${ }^{3}$. O objetivo desse trabalho foi o desenvolvimento de CLN contendo ciprofloxacina e posteriormente incorporados em hidrogéis.

\section{Resultados e Discussão}

Os NLC foram preparados pelo método de emulsificação ultrassônica, a partir de uma composição padrão de um lipídio sólido e líquido, estabilizados por um surfactante e acrescidos de 0,3\% de CIP. Medidas de espalhamento de luz dinâmico (DLS) revelaram tamanhos de partícula da ordem de $240 \mathrm{~nm}, \mathrm{PDI}>0,2$ e ZP negativos ( -26,1 a $39,1 \mathrm{mV})$ que se mantiveram ao longo de 1 ano de armazenamento na temperatura ambiente (Figura 1).
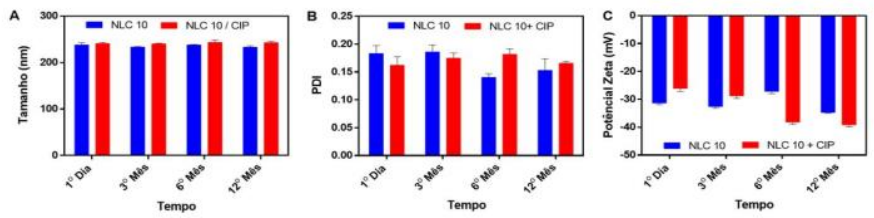

Figura 1: Diâmetro médio (A), PDI (B) e potencial Zeta (C) dos CLN (controle sem fármaco) e CLN-CIP, medidos por DLS durante 365 dias de estocagem a $25^{\circ} \mathrm{C} \pm 2$.

Hidrogéis de poloxamer $(\mathrm{PL})$ e alginato $(\mathrm{AL})$ foram usados para incorporar as formulações CLN e CLN-CIP. Nas medidas com amostras recém-preparadas em ambos hidrogéis, analisadas a 25 e $37^{\circ} \mathrm{C}$, para observar modificação das nanopartículas em ambos os géis. As nanopartículas apresentaram praticamente 0 mesmo tamanho e PDI, independentemente do polímero e da temperatura (Figura 2).

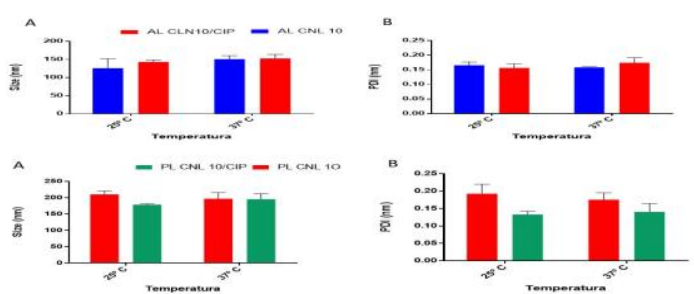

Figura 2: Diâmetro médio (A) e PDI (B) dos CLN (controle sem fármaco) e CLN-CIP incorporados nos géis de PL e $\mathrm{AL}$, nas temperaturas de $25^{\circ}$ e $37^{\circ} \mathrm{C}$.

Ensaios de liberação in vitro (Figura 3) revelaram que a encapsulação de CIP nas nanopartículas e dessas nos hidrogéis promoveram liberação sustentada com percentuais de $97 \%$ e $71 \%$, respectivamente, após $24 \mathrm{~h}$.

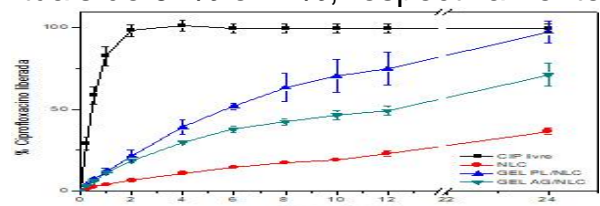

Figura 3: Perfil de liberação in vitro de CIP livre, encapsulada no CLN10 e os hidrogéis de pluronic e alginato, na temperatura de $37^{\circ} \mathrm{C}$.

\section{Conclusões}

A formulação CLN-CIP mostrou boa estabilidade ao longo de 1 ano de estocagem. Quando incorporadas em hidrogéis de $\mathrm{PL}$ e $\mathrm{AL}$, as nanopartículas se mantiveram íntegras, e promoveram liberação sustentada do antimicrobiano por mais de $1 \mathrm{dia}$, indicando que o sistema híbrido (NLC em hidrogel) pode ser útil para aplicação tópica. Em relação as atividades antimicrobianas, foram demonstrados que a formulação de CLN potencializaram a ação antibacteriana de CIP, resultados estes demonstrados no ano anterior.

\section{Agradecimentos}

Os autores agradecem o apoio financeiro FAPESP (\# 2014/14457-5) e bolsa PIBIt/CNPq (T.C.M).

${ }^{1}$ YALVAC, I. S et al. Cataract Refract Surg, 29, 487, 2003.

2 BELOQUI, A. et al. Nanomed. Nanotechnol. Biol. Med. 12, 143, 2016.

${ }^{3}$ QIU, Y. \& PARK, K. Adv.Drug Deliv.Rev.53, 321, 2001. 